\author{
Asian Journal of \\ Medical and Biological Research \\ ISSN 2411-4472 (Print) 2412-5571 (Online) \\ www.ebupress.com/journal/ajmbr
}

\title{
Article \\ Effect of feeding concentrate on the reproductive efficiency of repeat breeder cows at Baghabari milk shed area
}

\author{
MS Islam ${ }^{1}$, Gk Deb ${ }^{2}$, MA Habib ${ }^{2}$, M. Ershaduzzaman ${ }^{2}$, Md. Yousuf Ali ${ }^{1}$, MH Kabir $^{1}$, Most. Sumona Akter ${ }^{4}$, M \\ Aktaruzzaman $^{3}$, M Salah Uddin ${ }^{3}$, SM Rahman $^{1}$ and MF Afroz ${ }^{2}$ \\ ${ }^{1}$ Bangladesh Livestock Research Institute, Regional Station, Baghabari, Sirajgonj-6770, Bangladesh \\ ${ }^{2}$ Bangladesh Livestock Research Institute, Savar, Dhaka-1341, Bangladesh \\ ${ }^{3}$ Milkvita, Baghabarighat Branch, Shahjadpur, Sirajgonj - 6770, Bangladesh \\ ${ }^{4}$ Central Cattle Breeding and Dairy Farm, Savar, Dhaka-1341, Bangladesh
}

*Corresponding author: MS Islam, Bangladesh Livestock Research Institute, Regional Station, Baghabari, Sirajgonj-6770, Bangladesh. E-mail: siraj_blri@yahoo.com

Received: 07 March 2018/Accepted: 15 March 2018/ Published: 29 March 2018

\begin{abstract}
A total of nine Repeat Breeder (RB) cows consisting three cows in each of the three treatment groups were selected at farmer's house of Nukali village of Sahjadpur Upazila under Sirajgonj district to know the feeding effect of concentrate feed on reproductive efficiency of RB cows. Concentrate feeds were given to the $\mathrm{RB}$ cows based on their body weight and milk production. Same management like housing, watering and quantity of green grasses and straw were ensured during the experimental period. Heat detection of cow was done by Draminski Estrous Detector (DRAMINSKI) to perform artificial insemination in standing heat period. Experimental diet samples were tested for chemical compositions in the laboratories. Data were statistically analyzed by the computer software program of SPSS. Days open or calving to conception interval were $13.00 \pm 3.51,9.33 \pm 1.20$ and $15.33 \pm 1.45$ months for treatment group $\mathrm{T}_{1}, \mathrm{~T}_{2}$ and $\mathrm{T}_{3}$, respectively. All experimental cows $(100 \%)$ of treatment group one $\left(\mathrm{T}_{1}\right)$ were become pregnant whereas no cows $(0 \%)$ were conceived in treatment group $\left(\mathrm{T}_{3}\right)$. Mean conception rate of all experimental cows was $0.56 \pm 0.18$ with no significant difference. The results from the present study showed that dietary status of crossbred dairy cow can improve the reproductive efficiency like the conception rate RB cows. It's would be concluded that diet containing optimum level of $\mathrm{CP}, \mathrm{Ca}$ and $\mathrm{P}$ might be played a vital role for maximum conception rate of RB cows which clearly indicates the dietary intervention effect for improving the breeding efficiency of repeat breeder cows.
\end{abstract}

Keywords: concentrate feed; repeat breeder cows; reproductive efficiency; conception rate

\section{Introduction}

Repeat breeding (RB) is a significant problem in dairy farmers under artificial insemination (AI) programs especially in the developing countries of the world like Bangladesh. It is typically defined that a cow isn't conceived after three or more artificial insemination by an inseminator. Incidence of repeat breeding in dairy cows has been reported by several studies ranging from $11.8 \%$ to $62 \%$ resulting economic loss in dairy cattle production (Lafi et al., 1992; Katagiri and Takahashi, 2004; Yosuf et al., 2012). Dairy farmers have been suffering a lot due to this evolving trouble. Severity of the RB are extending gradually by increasing insemination, treatment, feed, labour and management cost, increase calving interval and culling rates and decreasing calf and milk production (Lucy, 2001; Islam et al., 2017). The detrimental influence of repeat breeding is increased the number of services per conception ranging from 4 to 24 services per conception in crossbred dairy cows (Islam et al., 2017). Milk shed area of Baghabari is environmentally most favorable places for commercial dairy cattle production in Bangladesh. Repeat breeding problem is always caused a great economic loss by increasing the cost of production. As a result, reproductive life of dairy cattle especially 
managing the repeat breeding problem for obtaining regular conception is a great challenge for dairy cattle production because of repeat breeding reduces the productivity and profitability of dairy farming. Intensification of the incidence rate of RB problems in cows reduces the milk and calf production in their lifespan (Butler, 2000; Lean et al., 2008; Thatcher et al., 2011). However, repeat breeding is a great problem in dairy cows in the studied areas. That's why; a preliminary work was done to identify the possible causes for repeat breeding problems in Baghabari milk shed area. Finally major causes associated to repeat breeding problems in dairy cows were identified by survey, rectal palpation of RB cows, nutritional analysis of concentrate feed and frozen semen quality analysis. Incidence of repeat breeding problems was found about 29 percent in the studied areas by that recent preliminary study. Poor nutrition was found one of the most important factors among all possible causes those were identified by (Islam et al., 2017). Nutritional deficiency was observed from poor nutrient density in the diet or poor quality diet, inadequate quantity of diet fed and insufficient to diet. Repeat breeding causes a great loss to the farmers in terms of milk and calves production. Hence, it is necessary to minimize the RB problem for producing more milk to achieve the Sustainable Development Goals (SDGs) of Bangladesh. A few works are done to know the effect of concentrate feeding on breeding efficiency of repeat breeder cows. Therefore, this study was undertaken with the objective to know the effect of concentrate feeds on the reproductive efficiency of repeat breeder cows at Baghabari milk shed areas.

\section{Materials and Methods}

A total of nine RB cows consisting three cows in each of the three treatment groups were selected at farmer's house of Nukali village of Sahjadpur Upazila under Sirajgonj district to know the feeding effect of concentrate feed on reproductive efficiency of dairy cows. Previous history of breeding system, health status, productive and reproductive performances were considered before selecting RB cows. Experimental cows were checked by rectal palpation to identify the cows free from any defect of reproductive organs and reproductive diseases. Concentrate feeds were given to the RB cows based on their body weight and milk production. Same management like housing, watering and quantity of green grasses and straw were ensured during the experimental period. Heat detection of cow was done by Draminski Estrous Detector (DRAMINSKI) to perform artificial insemination in standing heat period. Same quality semen was used for artificial insemination of the RB cows. Pregnancy test was performed after artificial insemination (AI) on 50 days. Data were recorded on feeds, semen, previous breeding history, health status, reproductive performances, conception etc. A total of nine feed samples randomly taken and three samples from each of the treatment groups were analyzed at the Nutrition Laboratory under Animal Production Research Division of BLRI and Animal Nutrition Laboratory of the Department of Livestock Services (DLS), Farmgate, Dhaka. Data were statistically analyzed by the computer software program of SPSS. Feed ingredients and their chemical composition were shown in Table 1 and Table 2, respectively.

\section{Results and Discussion}

Different productive and reproductive performances of experimental cows in three treatment groups are given in Table 3. Body weight was $374.67 \pm 4.37,323.67 \pm 46.56$ and $352.33 \pm 21.61 \mathrm{~kg}$ respectively with no significant difference among different treatment groups of $\mathrm{T}_{1}, \mathrm{~T}_{2}$ and $\mathrm{T}_{3}$. Mean age of experimental cows were ranged from more than 48 to 56 month in different treatment groups. Almost all experimental cows were in same parity in three treatment groups. Peak milk production was found lowest $(9 \mathrm{l} / \mathrm{d} / \mathrm{c})$ in treatment group $\left(\mathrm{T}_{1}\right)$ while highest in $T_{2}$ and $T_{3}$ groups $(17 \mathrm{l} / \mathrm{d} / \mathrm{c})$. Milk production of cows was highest in $\mathrm{T}_{1}$ and $\mathrm{T}_{3}$ groups while lowest in $\mathrm{T}_{2}$ group during dietary intervention. First heat after calving were $7.67 \pm 4.70,6.00 \pm 0.58$ and $5.33 \pm 0.67$ months in treatment group $\mathrm{T}_{1}, \mathrm{~T}_{2}$ and $\mathrm{T}_{3}$, respectively. Days open or calving to conception interval were13.00 \pm 3.51 , $9.33 \pm 1.20$ and $15.33 \pm 1.45$ months for treatment group $\mathrm{T}_{1}, \mathrm{~T}_{2}$ and $\mathrm{T}_{3}$, respectively. These results are fully contradicts with the findings of Ferguson et al., 1980; Garcia Bojalil et al., 1998; Hotler et al., 1992; Hutchinson et al., 2011; Moallem et al., 2010; Salfer et al.,1995 and Sklan et al., 1989 who reported the calving to pregnancy interval ranging from 73 to 123 days.

Number of artificial insemination (AI) done in experimental repeat breeder cows before and after intervention are shown in Table 4. No significant difference was found among different treatment groups for the number of artificial insemination before and after intervention. It was clearly seen that about 6 times AI services were done in the experimental cows of three treatment groups before intervention which ultimately increasing long calving interval and decreasing milk and calf production. 
Table 1. Feed ingredients used in different dietary groups.

\begin{tabular}{lllcl}
\hline SI. No & Feed ingredients & \multicolumn{3}{c}{ Treatment groups } \\
\cline { 3 - 5 } & & $\mathbf{T}_{\mathbf{1}}$ & $\mathbf{T}_{\mathbf{2}}$ & $\mathbf{T}_{\mathbf{3}}$ (Control) \\
\hline 1 & Wheat bran & 40 & 55 & 33 \\
2 & Khesari bran & 26 & 26 & - \\
3 & Lentil bran & 5 & - & 7 \\
4 & Matikalai & 5 & - & 60 \\
5 & Rice polish & 5 & - & - \\
6 & Til oil cake & 13 & 13 & - \\
7 & DCP & 4.50 & 4.5 & - \\
8 & Fish meal & 1 & 1 & - \\
9 & Salt & 0.50 & 0.5 & - \\
10 & Vitamin mineral premix & 0.70 & - & 100.00 \\
\hline
\end{tabular}

Table 2. Chemical composition of experimental diets among different treatment groups.

\begin{tabular}{|c|c|c|c|c|c|c|c|}
\hline \multirow{2}{*}{$\begin{array}{l}\text { Treatment } \\
\text { groups }\end{array}$} & \multirow{2}{*}{$\begin{array}{l}\text { DM } \\
\text { (\% fresh) }\end{array}$} & \multicolumn{6}{|c|}{ Chemical composition (\% DM) } \\
\hline & & Ash & $\mathbf{C P}$ & ADF & NDF & $\mathbf{C a}$ & $\mathbf{P}$ \\
\hline $\mathrm{T}_{1}$ & 88.34 & 12.98 & 14.14 & 29.77 & 57.13 & 2.16 & 0.53 \\
\hline $\mathrm{T}_{2}$ & 87.22 & 11.43 & 13.21 & 46.14 & 58.80 & 1.48 & 0.47 \\
\hline $\mathrm{T}_{3}$ & 88.53 & 9.42 & 10.49 & 45.84 & 62.44 & 0.60 & 0.33 \\
\hline
\end{tabular}

Table 3. Productive and reproductive status of experimental cows.

\begin{tabular}{|c|c|c|c|c|c|}
\hline \multirow{3}{*}{$\begin{array}{l}\text { Traits } \\
\text { Parameters }\end{array}$} & \multirow[t]{3}{*}{ No } & \multicolumn{3}{|c|}{ Treatment group } & \multirow{3}{*}{ Level of significance } \\
\hline & & \multicolumn{3}{|c|}{ Mean \pm SE } & \\
\hline & & $T_{1}$ & $\mathbf{T}_{2}$ & $\mathbf{T}_{3}($ Control) & \\
\hline Body weight (kg) & 3 & $374.67 \pm 4.37$ & $323.67 \pm 46.56$ & $352.33 \pm 21.61$ & NS \\
\hline Age $(m)$ & 3 & $52.00 \pm 1.53$ & $48.33 \pm 10.10$ & $56.67 \pm 3.18$ & NS \\
\hline Parity & 3 & $1.00 \pm 0.00$ & $1.00 \pm 0.577$ & $1.33 \pm 0.33$ & NS \\
\hline Peak milk production $(1 / \mathrm{d} / \mathrm{c})$ & 3 & $17.67 \pm 0.88$ & $9.00 \pm 4.51$ & $17.66 \pm 2.60$ & NS \\
\hline $\begin{array}{l}\text { Milk production during } \\
\text { intervention }(1 / \mathrm{d} / \mathrm{c})\end{array}$ & 3 & $10.67 \pm 0.67$ & $5.00 \pm 2.52$ & $10.00 \pm 1.15$ & NS \\
\hline First heat after last calving (m) & 3 & $5.33 \pm 0.88$ & $3.67 \pm 0.33$ & $6.00 \pm 0.58$ & NS \\
\hline $\begin{array}{l}\text { Days open/calving to pregnancy } \\
\text { interval }(\mathrm{m})\end{array}$ & 3 & $13.00 \pm 3.51$ & $9.33 \pm 1.20$ & $15.33 \pm 1.45$ & NS \\
\hline
\end{tabular}

NS=Non-significance

Table 4. Number of AI service in experimental cows before and after intervention.

\begin{tabular}{llllll}
\hline \multirow{2}{*}{$\begin{array}{l}\text { Traits } \\
\text { Parameters }\end{array}$} & \multirow{2}{*}{ No } & \multicolumn{3}{c}{ Treatment group } & \multirow{2}{*}{$\begin{array}{c}\text { Level of } \\
\text { significance }\end{array}$} \\
\cline { 3 - 5 } & & $\mathbf{T}_{1}$ & $\mathbf{T}_{2}$ & $\mathbf{T}_{3}$ (Control) & Mean $\pm \mathbf{S E}$ \\
\hline $\begin{array}{l}\text { No of AI service before } \\
\text { intervention }\end{array}$ & 3 & $7.67 \pm 4.70$ & $6.00 \pm 0.58$ & $5.33 \pm 0.67$ & $\mathrm{NS}$ \\
No of AI service after intervention & 3 & $2.33 \pm 0.33$ & $2.67 \pm 0.33$ & $1.67 \pm 1.20$ & $\mathrm{NS}$ \\
\hline
\end{tabular}

NS=Non-significance

Table 5. Conception rate among three treatment groups.

\begin{tabular}{lllll}
\hline Treatment group & No. of cows pregnant & \% pregnancy & Mean \pm SE & Level of significance \\
\hline $\mathrm{T}_{1}$ & 3 & 100 & & \\
$\mathrm{~T}_{2}$ & 2 & 66.67 & $0.56 \pm 0.18$ & NS \\
$\mathrm{T}_{3}$ & 0 & 0 & & \\
\hline
\end{tabular}

$\mathrm{NS}=$ Non-significance 
Table 5 shows conception rate of experimental cows among treatment groups. All experimental cows (100\%) of treatment group one $\left(\mathrm{T}_{1}\right)$ were become pregnant whereas no cows $(0 \%)$ were conceived in treatment group $\left(\mathrm{T}_{3}\right)$. On the other hand, about 67 percent of cows were become pregnant in the treatment group $\left(\mathrm{T}_{2}\right)$. The results of the present study may be the effect of dietary intervention in experimental cows. The result is agreed with the findings of Lamond., 1970; Ferguson et al., 1989; Blanchard et al., 1990; Chagas et al., 2007 and Rodney et al., 2015 who opined that nutritional status of animal alter the reproductive efficiency of cow. Mean conception rate of all experimental cows was $0.56 \pm 0.18$ with no significant difference that might be the small of cows in each treatment group.

\section{Conclusions}

The results from the present study it can be concluded that dietary status of crossbred dairy cow can improve the reproductive efficiency like the conception rate RB cows. It's clearly indicated that diet containing optimum level of CP, Ca and P might be played a vital role for maximum conception rate of RB cows. It's also observed that vitamin-mineral premix based cattle fertility pack might be influenced the maximum pregnancy rate in treatment group $\left(\mathrm{T}_{1}\right)$ compared to other treatment groups.

\section{Conflict of interest}

None to declare.

\section{Reference}

Blamchard T, J Ferguson and L Love, 1990. Effect of dietary crude protein type on fertilization and embryo quality in dairy cattle. Am. J. Vet. Res., 51: 905-908.

Chagas L, MJJ Bass, D Blache, CR Burke, JK, Kay, DR Lindsay, MC Luch, GB Martin, S Meier, FM Rhodes, JR Roche, WW Thatcher and R Webb, 2007. New perspectives on the roles of nutrition and metabolic priorities in the sub-fertility of producing dairy cows. J. Dairy Sci., 90: 4022-4032.

Ferguson JD and W Chalupa, 1989. Impact of protein nutrition on reproduction in dairy cattle. J. Dairy Sci., 72: 746-766.

Ferguson JD, W Sklan, Chalupa and D Kronfeld, 1990. Effects of hard fats on in vitro and in vivo rumen fermentation, milk production and reproduction in dairy cows. J. Dairy Sci., 73: 2864-2879.

Garcia-Bojalil CC, C Staples, J Risco, Savio and W Thatcher, 1998. Protein degradability and calcium salts of long-chain fatty acids in the diet of lactating dairy cows: Reproductive responses. J. Dairy Sci., 81: 13741384.

Holter J, H Hayes, JR Urban and A Duthie, 1992. Energy balance and lactation response in Holstein cows supplemented with cottonseed with or without calcium soap. J. Dairy Sci., 75: 1480-1494.

Hutchinson I, MJ Deveth, C Stanton, R.J Dewhurst, P Lonergan, AC Evans and ST Butler, 2011. Effects of lipid-encapsulated conjugated linoleic acid supplementation on milk production, bioenegetic status and indicators of reproductive performance in lactating dairy cow. J. Dairy Sci., 78: 308-317.

Katagiri S and Y Takahashi, 2004. Changes in EGF concentrations during estrous cycle in bovine endometrium and their alterations in repeat breeder cows. Theriogenology, 62: 103-112.

Lafi SQ and JB Kaneene, 1992. Epidemiological and economic study of the repeat breeder syndrome in Michigan dairy cattle. I. Epidemiological modeling. Prev. Vet. Med., 14: 87-98.

Lamond DR, 1970. Nutrient status in relation to reproduction. J. Anim. Sci., 30: 322.

Lucy MC, 2001. Reproductive loss in high-producing dairy cattle: where will it end? J. Dairy Sci., 84: 12771293.

Moallem U, H Lehrer, M Zachut, L Livshit, and S Yacoby, 2010. Production performance and pattern of milk fat depression of high-yielding dairy cows supplemented with encapsulated conjugated linoleic acid. Animal, 4: 641-652.

Islam MS, GK Deb, TN Nahar, M Ershaduzzaman, MA Habib, MY Ali, MH Kabir, MA Yousuf and MF Afroz, 2017. Identification of possible causes of repeat breeding in dairy cows at Baghabari milk shed areas, Sirajgonj, Bangladesh. Asian J. Med. Biol. Res., 3: 186-190.

Rodney RM, P Celi, W Scott, K Breinhild and IJ Lean, 2015. Effects of dietary fat on fertility of dairy cattle: A meta-analysis and meta-regression. J. Dairy Sci., 98: 5601-5620.

Salfey J, J Linu, D Otterby, W Hansen and D Jolmson, 1995. Early lactation responses of Holstein cows fed a rumen-insert fat prepartum, postpartum, or both. J. Dairy Sci., 78: 368-377.

SKlan D, E Bogin and Y Avider, 1989. Feeding calcium soaps of fatty acids to lactating cows: Effect on production, body condition and blood lipids. J. Dairy Res., 56: 675-681.

Yosuf M, L Rahim, MA Asja and A Wahyudi, 2012. The incidence of repeat breeding in dairy cows under tropical condition. http://medpet.journal.ipb.ac.id. 